\title{
Effect of Carbon/Nitrogen on Elimination of Coliforms during Composting of Sewage Sludge, Dairy Manure and Sawdust
}

\author{
Fatih Sevki Erkus (Corresponding author) \\ Department of Biosystems Engineering, Faculty of Agriculture, \\ Van Yuzuncu Yil University, Van, Turkey \\ E-mail: fatiherkus@gmail.com \\ Pinar Setlek \\ Department of Biosystems Engineering, Faculty of Agriculture, \\ Van Yuzuncu Yil University, Van, Turkey \\ E-mail: setlek65@gmail.com
}

\begin{abstract}
Composting is a solid waste management alternative to reduce potential hazards in the converting of sewage sludge into reusable material on land. But inefficiency of traditional composting process rate lowers its demand. In-vessel system could provide more effective pathogens reduction and produce pathogen-free soil amendments in comparison with traditional composting systems. In order to achieve successful composting process environmental factors such as temperature, moisture, aeration and nutrients should be sufficiently controlled.

This study was undertaken to assess the effect of the carbon/nitrogen $(\mathrm{C} / \mathrm{N})$ ratio on reduction or elimination of total and fecal coliforms in co-composting of sewage sludge with dairy manure and sawdust using an in-vessel system under controlled conditions. Temperature, $\mathrm{pH}$ and $\mathrm{C} / \mathrm{N}$ values were used for consideration of the stabilization of the composting process.

In this study the minimum temperature of composting process was set to $40 \mathrm{oC}$ by temperature controlled external heater. Initial mesophilic phase occurred within 2 days followed by the thermophilic phase, which lasted for about 10 days. Monitored parameters featured reaction trends to those obtained changes in the mesophilic, thermophilic and maturation phases. A high $\mathrm{C} / \mathrm{N}$ reduction observed for high initial $\mathrm{C} / \mathrm{N}$ mixtures (30 and 40) within 7 days of composting. Low initial $\mathrm{C} / \mathrm{N}$ mixture (20) showed slightly $\mathrm{C} / \mathrm{N}$ reduction during composting. A higher ratio of $\mathrm{C} / \mathrm{N}$ preparations led to a higher stabilization rates but higher coliforms reduction achieved with low $\mathrm{C} / \mathrm{N}$ ratios.
\end{abstract}

Keywords: In-vessel composting, dairy manure, Dewatered sewage sludge, fecal coliforms.

DOI: $10.7176 / \mathrm{JSTR} / 5-7-01$

\section{Introduction}

Composting is defined as the aerobic biological degradation of organic substrates that results thermophilic temperatures to produce stable, free of pathogens, and usable final product for agricultural purposes (Haug, 1993).

The sanitization of the composting is assessed using both pathogen indicator microorganisms and specific pathogens. Specific pathogen detection is difficult and time consuming, therefore total and fecal coliforms are used as indicators of pathogen microorganisms for sewage sludge utilization in agriculture (Xu et al., 2009; Epstein et al., 1976; Larney et al., 2003; Briancesco et al., 2008; Rashad et al., 2010; Topal et al., 2016). However, there is a growing public concern for compost-borne pathogens reaching to agricultural land by soil amendments (Pandey et al., 2016). The main drawbacks of composting include the inefficiency of composting process rate, thus 15-40 days of composting is recommended to eliminate pathogens (Dumontet et al, 1999).

Composting time can be reduced and pathogen elimination can be achieved using in-vessel composting system. Pandey et al. (2016) showed that using fixed temperature achieved by external heater $\left(60^{\circ} \mathrm{C}\right)$ in 
in-vessel system could provide more effective pathogens reduction and produce pathogen-free soil amendments in comparison with traditional composting systems. Their pilot-scale setting achieved compost sanitization in $8-10 \mathrm{~h}$ using a feedstock consist of food waste, horse manure, palm-tree waste, and green waste.

In order to achieve successful composting process environmental factors such as temperature, moisture, aeration and nutrients should be sufficiently controlled (Epstein, 1997). Carbon and nitrogen balance of feedstock is one of the important factors affecting compost quality and is recommended at a ratio of 25 30 as optimum ratio (Huang et al., 2004).

In this study, in-vessel composting of sewage sludge, dairy manure and sawdust mixtures was investigated at different initial $\mathrm{C} / \mathrm{N}$ ratios and throughout the experimentation, temperature, $\mathrm{pH}, \mathrm{C} / \mathrm{N}$ and total and fecal coliforms numbers were measured.

\section{Materials and Methods}

\subsection{Composting Materials}

Dairy manure and sawdust were used as composting materials for processing with sewage sludge. Dewatered sewage sludge was sent from Edremit Wastewater Treatment Plant (WWTP) located in Van, Turkey. The sewage sludge was stabilized by aerobic digestion, mechanically dewatered in WWTP and is being disposed of at the landfill site. Fresh dairy manure was collected from the farm at Van Yuzuncu Yil University. Sawdust obtained from local sawmill was used as bulking agent. The main characteristics of sewage sludge, dairy manure and sawdust are given on dry weight basis in Table 1. Initial moisture content and $\mathrm{C} / \mathrm{N}$ ratios of the mixtures were adjusted to $60 \%$ and 20:1, 30:1 and 40:1, respectively.

Table 1 . The main characteristics of sewage sludge, dairy manure and sawdust.

\begin{tabular}{|l|l|l|l|}
\hline Materials & Sewage Sludge & Dairy Manure & Sawdust \\
\hline Moisture Content (\%) & 73.5 & 86.2 & 10.2 \\
\hline Volatile Solid (\%TS) & 74.9 & 84.0 & 97.5 \\
\hline $\mathrm{pH}$ & 7.9 & 7.5 & - \\
\hline Total Carbon (\%TS) & 37.8 & 39.4 & 45.8 \\
\hline Total Nitrogen (\%TS) & 6.5 & 1.1 & 0.1 \\
\hline Carbon/Nitrogen & 5.8 & 34.9 & 458 \\
\hline
\end{tabular}

\subsection{Experimental setup}

In this study three in-vessel composting systems were used based on described by Cekmecelioglu et al. (2005). Bioreactors were made of stainless steel, covered with glass wool to minimize heat loss and a sampling port was mounted from the top of the reactor vessel (Fig. 1). The bioreactors had an effective volume of $10 \mathrm{~L}$ with an inner diameter of $22 \mathrm{~cm}$ and height of $33 \mathrm{~cm}$.

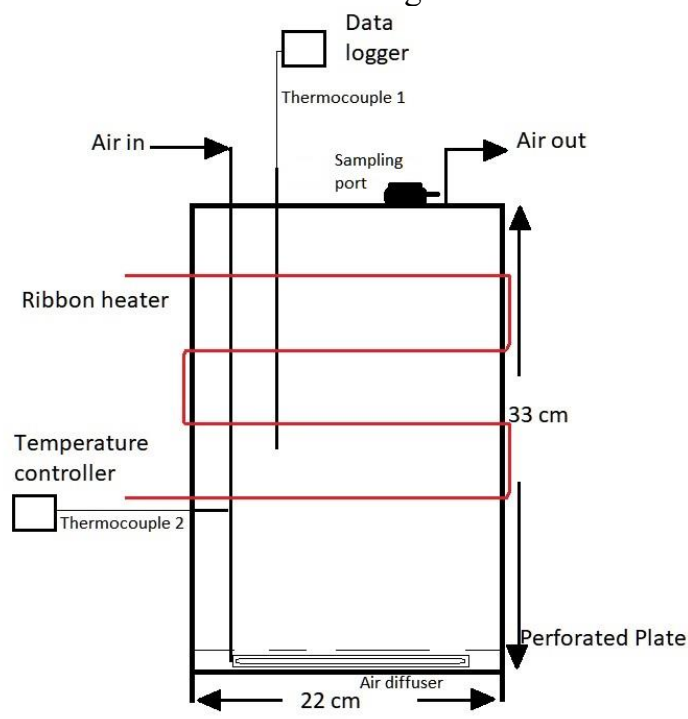

Figure 1. In-vessel composting system. 
Temperature of the system was recorded by a multiple channel data logger at 10 min intervals. A thermocouple was located at the center of the compost mixture and other thermocouple was located at the bottom center of the mixture. Temperature controller was connected to the external ribbon heater set at $40{ }^{\circ} \mathrm{C}$ in order to accelerate microbial acclimation and to avoid cooling effect of aeration system. Air was supplied by aquarium pumps connected to each bioreactor at an airflow rate of $180 \mathrm{ml} / \mathrm{min}$. The mixtures were composted for 20 days and samples were obtained at the beginning, on the $2^{\text {nd }}, 4^{\text {th }}, 7^{\text {th }}, 14^{\text {th }}$ and at the end of the composting process.

\subsection{Chemical and Microbiological Analysis}

Compost samples were analyzed for moisture content, $\mathrm{C} / \mathrm{N}$ ratio and $\mathrm{pH}$. The $\mathrm{pH}$ of compost was analyzed by adding $5 \mathrm{~g}$ samples to $250 \mathrm{ml}$ of deionized water followed by measurement with a $\mathrm{pH}$ meter. Total carbon and nitrogen contents were measured using an elemental analyzer (Costech Elemental Analyzer ESC 4010). Moisture content was determined by drying for $24 \mathrm{~h}$ and weighing of a $5 \mathrm{~g}$ sample. Bacteriological analysis consisted of determination of plate counts of total coliform and fecal coliform bacteria on solid cultivation media according to Standard Methods 9222 D (APHA, 1989) and ISO 93081 (ISO/FDIS 9308-1, 2000), respectively.

\section{Results}

Microbial community activities during the composting process were determined by changes in $\mathrm{C} / \mathrm{N}$ ratio, temperature, $\mathrm{pH}$ and total and fecal coliforms numbers. All parameters were featured reaction to those obtained changes in the mesophilic, thermophilic and maturation phases.

\subsection{Temperature profile}

The value of temperature gives information about the level of sanitation capacity of the process as its level indicates which biological reaction occurs (Khalil et al., 2011). In the present study, the changes in temperature during composting in different initial $\mathrm{C} / \mathrm{N}$ ratios are shown in Fig. 1.

At the beginning of the process temperatures of the materials were about $40{ }^{\circ} \mathrm{C}$ as the minimum temperature was set to $40{ }^{\circ} \mathrm{C}$ by temperature controlled external heater. Temperatures increased to 49.4, 48.5, and 53.8 after 2 days of composting in $\mathrm{C} / \mathrm{N}$ ratios of 20, 30 and 40, respectively. Maximum temperatures were reached after 2 days and maintained at the end of the $7^{\text {th }}$ day. In maturation phase temperatures decreased slowly and reached to $45.2,43.4$ and 41.0 for $\mathrm{C} / \mathrm{N}$ ratios of 20,30 and 40 , respectively. Highest temperature profile was maintained by $\mathrm{C} / \mathrm{N}$ ratio of 40 .

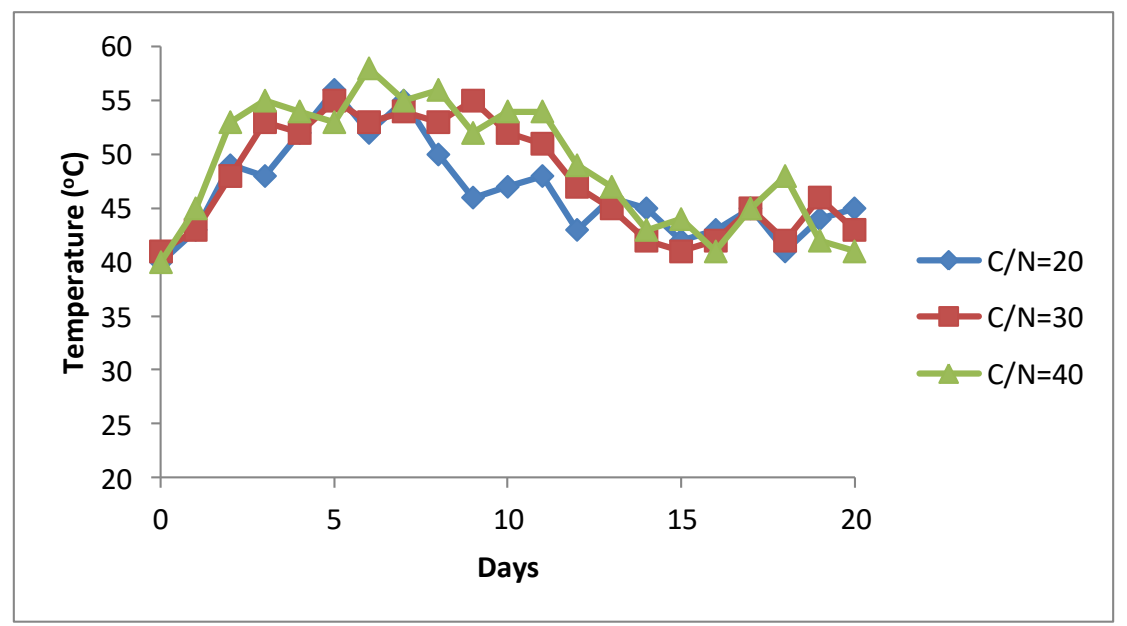

Figure 2. Changes in temperature during the composting of sewage sludge, dairy manure and sawdust mixtures using different initial $\mathrm{C} / \mathrm{N}$.

\section{2. pH Profile}

The average $\mathrm{pH}$ change values during composting are shown in Fig. 3. In general $\mathrm{pH}$ values are increased during composting process but reached neutral values at the end of the process except for $\mathrm{C} / \mathrm{N}$ ratio of 20.That case thought to be due to incomplete digestion of the mixture cause of high nitrogen content.

3 I P a g e www.iiste.org 


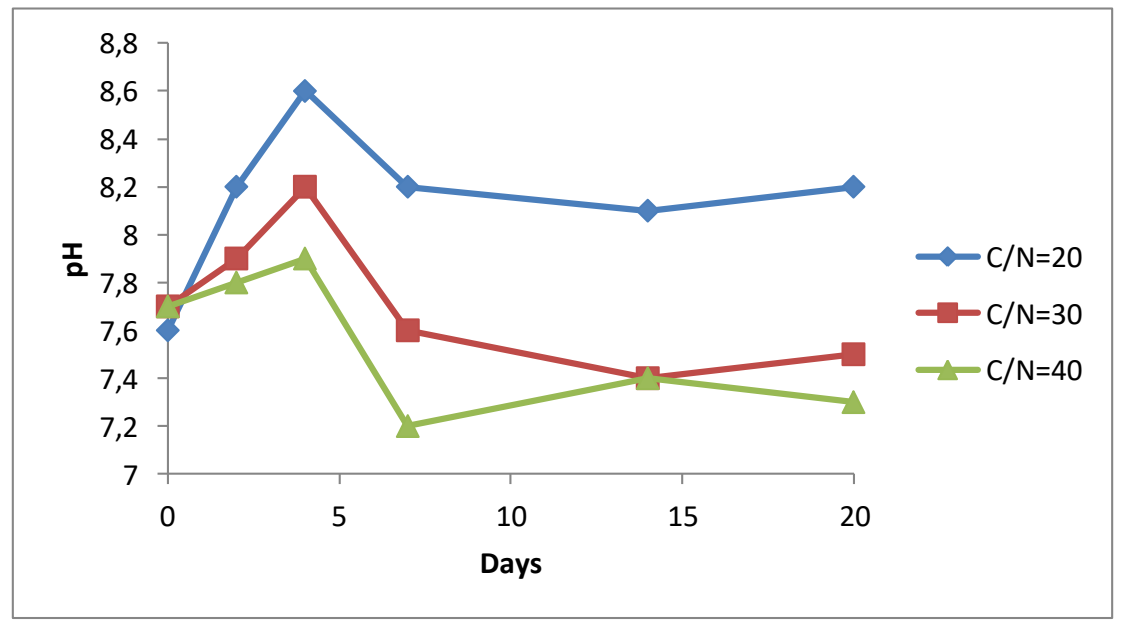

Figure 3. Changes in $\mathrm{pH}$ during the composting of sewage sludge, dairy manure and sawdust mixtures using different initial $\mathrm{C} / \mathrm{N}$.

\subsection{Changes in $\mathrm{C} / \mathrm{N}$ during the composting system}

The $\mathrm{C} / \mathrm{N}$ ratio is evaluated as an indicator parameter of organic matter decomposition degree (Khalil et al., 2011). Changes in $\mathrm{C} / \mathrm{N}$ ratios during composting are presented in Fig. 4. A high reduction observed for high $\mathrm{C} / \mathrm{N}$ ratios mixtures $(\mathrm{C} / \mathrm{N}=30$ and $\mathrm{C} / \mathrm{N}=40)$ within 7 days of composting. Low initial $\mathrm{C} / \mathrm{N}$ mixture $(\mathrm{C} / \mathrm{N}=20)$ showed slightly $\mathrm{C} / \mathrm{N}$ reduction.

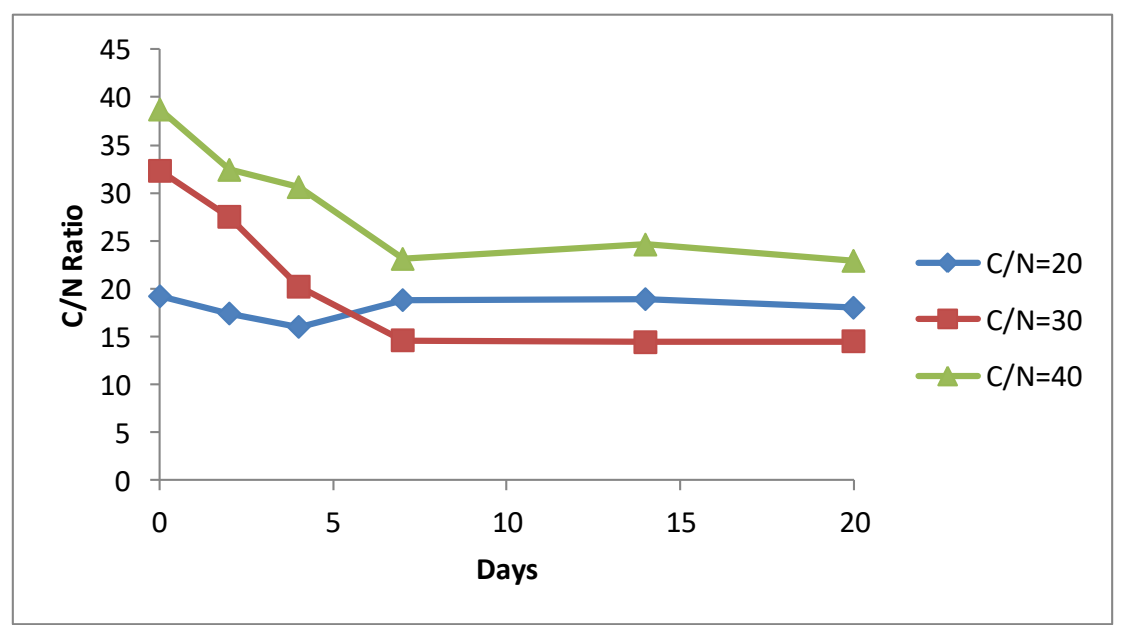

Figure 4. Changes in $\mathrm{C} / \mathrm{N}$ ratios during the composting of sewage sludge, dairy manure and sawdust mixtures using different initial $\mathrm{C} / \mathrm{N}$.

\subsection{Compost Sanitization}

Change of total and fecal coliforms numbers during the composting as coliform forming unit (cfu) are presented in Table 1. At the beginning of the composting process, the number of total and fecal coliforms counts ranged between $10^{8}$ and $10^{6} \mathrm{cfu} / \mathrm{g}$ and a fast decrease occurred by the thermophilic phase. In the $2^{\text {nd }}$ day of composting a higher ratio of $\mathrm{C} / \mathrm{N}$ mixtures $(\mathrm{C} / \mathrm{N}=30$ and $\mathrm{C} / \mathrm{N}=40)$ reached $10^{4}$ and $10^{5} \mathrm{cfu} / \mathrm{g}$ while low $\mathrm{C} / \mathrm{N}$ mixture $(\mathrm{C} / \mathrm{N}=20)$ achieved $8 \log 10$ reduction.

A higher ratio of $\mathrm{C} / \mathrm{N}$ preparations led to a higher stabilization rates but higher coliforms reduction achieved with low $\mathrm{C} / \mathrm{N}$ ratios $(\mathrm{C} / \mathrm{N}=20)$. This could be explained by the high $\mathrm{pH}$ stress on coliform organisms.

The numbers of total coliforms declined very similar to those of fecal coliforms during the composting process. It could be explained that the greater the number of fecal origin coliforms exists in the influent samples. 
Table 2. Changes in total and fecal coliforms counts during the composting of sewage sludge, dairy manure and sawdust mixtures using different initial $\mathrm{C} / \mathrm{N}$.

\begin{tabular}{|l|l|l|l|l|l|l|}
\hline \multirow{2}{*}{ Days } & \multicolumn{2}{l}{ cfu/gr dry compost } \\
\cline { 2 - 7 } & \multicolumn{2}{l|}{ Total coliforms } & \multicolumn{2}{l|}{ Fecal coliforms } \\
\cline { 2 - 7 } & $\mathrm{C} / \mathrm{N}=20$ & $\mathrm{C} / \mathrm{N}=30$ & $\mathrm{C} / \mathrm{N}=40$ & $\mathrm{C} / \mathrm{N}=20$ & $\mathrm{C} / \mathrm{N}=30$ & $\mathrm{C} / \mathrm{N}=40$ \\
\hline 0 & $2.110^{8}$ & $8.010^{8}$ & $1.010^{8}$ & $1.810^{6}$ & $8.010^{6}$ & $6.010^{6}$ \\
\hline 2 & $<10^{2}$ & $4.010^{4}$ & $6.610^{5}$ & $<10^{2}$ & $1.110^{4}$ & $3.010^{5}$ \\
\hline 4 & $<10^{2}$ & $<10^{2}$ & $<10^{2}$ & $<10^{2}$ & $<10^{2}$ & $<10^{2}$ \\
\hline 7 & $<10^{2}$ & $<10^{2}$ & $<10^{2}$ & $<10^{2}$ & $<10^{2}$ & $<10^{2}$ \\
\hline 14 & $<10^{2}$ & $<10^{2}$ & $<10^{2}$ & $<10^{2}$ & $<10^{2}$ & $<10^{2}$ \\
\hline 20 & $<10^{2}$ & $<10^{2}$ & $<10^{2}$ & $<10^{2}$ & $<10^{2}$ & $<10^{2}$ \\
\hline
\end{tabular}

\section{Conclusion}

Results showed that, at the beginning of composting, initial mesophilic phase occurred within 2 days followed by the thermophilic phase, which lasted for about 10 days.

During the composting process total and fecal coliforms declined in similar trends. Total and fecal coliforms decreased by the early stages of composting process and a fast decrease is observed at thermophilic temperatures. In mesophilic and maturation phases no coliform numbers increase observed as a result of setting minimum temperature constant at $40{ }^{\circ} \mathrm{C}$ by external heater. In the $2^{\text {nd }}$ day of composting a higher ratio of $\mathrm{C} / \mathrm{N}$ mixtures $(\mathrm{C} / \mathrm{N}=30$ and $\mathrm{C} / \mathrm{N}=40)$ decreased $10^{4}$ and $10^{5} \mathrm{cfu} / \mathrm{g}$ while low $\mathrm{C} / \mathrm{N}$ mixture $(\mathrm{C} / \mathrm{N}=20)$ achieved $8 \log 10$ reduction.

\section{References}

APHA, AWWA, WPCF, (1989). Standard methods for the examination of water and wastewater. Washington.

Briancesco R., Coccia A. M., Chiaretti G., Libera S. D., Semproni M., Bonadonna L., (2008). Assessment of microbiological and parasitological quality of composted wastes: health implications and hygienic measures. Waste Management \& Research, 26, 196-202.

Cekmecelioglu D., Demirci A., Graves R. E., (2005). Feedstock Optimization of In-Vessel Food Waste Composting Systems for Inactivation of Pathogenic Microorganisms. Journal of Food Protection, 68, 3, 589-596.

Déportes, I., Benoit-Guyod, J. L., Zmirou, D., Bouvier, M .C., (1998). Microbial disinfection capacity of municipal solid waste (MSW) composting. J. Appl. Microbiol., 85, 238-246.

Dumontet S., Dinel H., Baloda S. B., (1999). Pathogen Reduction in Sewage Sludge by Composting and Other Biological Treatments: A Review. Biological Agriculture and Horticulture, 16, 409430 .

Epstein E., Willson G. B., Burge W. D., Mullen D. C., Enkiri N. K., (1976). A Forced Aeration System for Composting Wastewater Sludge. Water Pollution Control Federation, 48, 4, 688-694.

Epstein, E., (1997). The Science of Composting. A Technomic Publishing Company.

Gumuscu B., Cekmecelioglu D., Tekinay T., (2015). Complete dissipation of 2,4,6-trinitrotoluene by in-vessel composting. $R S C A d v ., 5,51812$.

Haug, R.T., 1993. The Practical Handbook of Compost Engineering. Lewis Publishers, Boca Raton, USA. 
Huang G. F., Wong J. W. C., Wu Q. T., Nagar B. B., (2004). Effect of C/N on composting of pig manure with sawdust. Waste Management, 24, 805-813.

ISO/FDIS 9308-1, (2000). Norma International Standard. Water quality-Detection and enumeration of Escherichia coli and coliform bacteria.

Khalil A. I., Hassouna M. S., El-Ashqar H. M. A., Fawzi M., (2011). Changes in physical, chemical and microbial parameters during the composting of municipal sewage sludge. World J. Microbiol. Biotechnol, 27, 2359-2369.

Larney, F. J., Yanke, L. J., Miller, J. J., McAllister, T. A. (2003). Fate of coliform bacteria in composted beef cattle feedlot manure. J. Environ. Qual., 32, 1508-1515.

Pandey P. K., Vaddella V., Cao W., Biswas S., Chiu C., Hunter S., (2016). In-vessel composting system for converting food and green wastes into pathogen free soil amendment for sustainable agriculture. Journal of Cleaner Production, 139, 407-415.

Rashad F. M., Saleh W. D., Moselhy M. A., (2010). Bioconversion of rice straw and certain agroindustrial wastes to amendments for organic farming systems: 1. Composting, quality, stability and maturity indices. Bioresource Technology, 101, 5952-5960.

Şevik F., Tosun İ., Ekinci K., (2018). The effect of FAS and C/N ratios on co-composting of sewage sludge, dairy manure and tomato stalks. Waste Management, 80, 450-456.

The U.S. Environmental Protection Agency, (1995), A Guide to the Biosolids Risk Assessments for the EPA Part 503 Rule. [Online] Available:

http://www.epa.gov/region8/water/biosolids/pdf/625R92013ALL.pdf. (May 24, 2019)

Topal E. I. A., Ünlü A., Topal M., (2016). Effect of aeration rate on elimination of coliforms during composting of vegetable-fruit wastes. Int J. Recycl. Org Waste Agricult., 5, 243-249.

Xu W., Reuter T., Inglis G. D., Larney F. J., Alexander T. W., Guan J., Stanford K., Xu Y., McAllister T. A., (2009). A Biosecure Composting System for Disposal of Cattle Carcasses and Manure Following Infectious Disease Outbreak. Journal of Environmental Quality, 38, 2, 437-50. 